\title{
An integrated review of concepts and initiatives for mining the technosphere: towards a new taxonomy
}

\author{
Nils Johansson, Joakim Krook, Mats Eklund and Björn Berglund
}

\section{Linköping University Post Print}

\section{Tweet}

N.B.: When citing this work, cite the original article.

Original Publication:

Nils Johansson, Joakim Krook, Mats Eklund and Björn Berglund, An integrated review of concepts and initiatives for mining the technosphere:towards a new taxonomy, 2013, Journal of Cleaner Production, (55), 35-44.

http://dx.doi.org/10.1016/j.jclepro.2012.04.007

Copyright: Elsevier

http://www.elsevier.com/

Postprint available at: Linköping University Electronic Press

http://urn.kb.se/resolve?urn=urn:nbn:se:liu:diva-77301 


\section{An Integrated Review of Concepts and Initiatives for Mining the Technosphere: Towards a New Taxonomy}

Nils Johansson $_{a}{ }^{*}$; Joakim Krook ${ }_{a}$, Mats Eklund ${ }_{a}$, and Björn Berglund ${ }_{a}$.

*Corresponding author: Department of Management and Engineering, Environmental Technology and Management Linköping University, SE-581 83 Linköping, Sweden. nils.johansson@liu.se, +46(0)13 285629.

${ }^{a}$ Department of Management and Engineering, Environmental Technology and Management Linköping University, SE-581 83 Linköping, Sweden. joakim.krook@liu.se, mats.eklund@liu.se, bjorn.i.berglund@liu.se. 


\begin{abstract}
Stocks of finite resources in the technosphere continue to grow due to human activity, at the expense of decreasing in-ground deposits. Human activity, in other words, is changing the prerequisites for mineral extraction. For that reason, mining will probably have to adapt accordingly, with more emphasis on exploitation of previously extracted minerals.

This study reviews the prevailing concepts for mining the technosphere as well as actual efforts to do so, the objectives for mining, the scale of the initiatives, and what makes them different from other reuse and recycling concepts. Prevailing concepts such as "urban mining," however, are inadequate guides to the complexity of the technosphere, as these concepts are inconsistently defined and disorganized, often overlapping when it comes to which stocks they address. This review of these efforts and their potential is therefore organized around a new taxonomy based on the umbrella concept technospheric mining, defined as the extraction of technospheric stocks of minerals that have been excluded from ongoing anthropogenic material flows.

An analysis on the basis of this taxonomy shows that the prevailing mining initiatives are generally scattered and often driven by environmental factors, in which metal recovery is viewed as an additional source of revenue. However, development of technology, specialized actors and new business models and policy instruments, could lead to technospheric mining operations becoming a profit-driven business.
\end{abstract}

Key words: resource management; metal stocks; secondary resources; recycling; urban mining. 


\section{Introduction}

In a strict sense, "mining" refers to human extraction of useful minerals from the earth's crust (Hartman and Mutmansky, 2002), including metals such as copper, aluminum, iron and gold. Along with agriculture, mining was one of the early attributes of civilization (Hartman and Mutmansky, 2002) and has long been correlated with human progress, e.g. the "Bronze Age" or "Iron Age." Metals have also provided major incentives for human endeavors such as Marco Polo's journey to China, Columbus' discovery of the New World, and the gold rushes that led to the settlement of California and Australia (Rickard, 1932). At present, minerals and the related concerns of long-term resource availability are once again major drivers for a decisive transition, this time towards sustainability and recirculation of materials within the technosphere in the spirit of Frosch and Gallopoulos (1989). This societal transformation towards closed material loops has the possibility to fundamentally change the very essence of mining.

Ever since mining first appeared in its simplest form with flint extraction by Paleolithic communities 450,000 years ago (Lewis and Clark, 1964), human activities have successively moved metal resources from geological ores to applications in the technosphere ${ }^{1}$, in buildings, infrastructure and products. Industrialization drastically increased the rate of this relocation process of metal resources (Hayes, 2005). For specific metals such as iron and copper, it has been estimated that the current accumulation in the technosphere is comparable to or even exceeds the remaining amount in known geological ores (e.g. Lichtensteiger, 2002; Elshkaki et al., 2004; Spatari et al., 2005; Muller et al., 2006; Halada et al., 2009). Human activity, in other words, is changing the prerequisites for metal extraction. If this so, mining must adapt accordingly, with more emphasis on exploitation of already extracted minerals. This phenomenon is often traced back to the urban theorist Jane Jacobs (1969) who stated that: "In the highly developed economies of the future, it is probable that cities will become huge, rich and diverse mines of raw materials. These mines will differ from any now to be found because they will become richer the more and the longer they are exploited.[...]New veins, formerly overlooked, will be continually opened."

The increasing importance of technospheric stocks of secondary resources rather than geological stocks of virgin resources as a means to feed market demand has recently received attention, primarily in industrial ecology literature. Several descriptive concepts circulate in this research literature, referring to the potential of utilizing these "new mines" by expanding the traditional concept of mining to include urban mining (Brunner and Rechberger, 2004), mining above ground (UNEP, 2010), waste mining (Ayres et al., 2001), landfill mining (Cossu et al., 1996) and secondary mining (Pirrone and Mahaffey, 2005). So far, however, these "concepts" have remained undeveloped and primarily had brief mention in connection with material flow analysis, without specific details regarding exactly which technospheric stocks they address and what distinguishes them from each other as well as from other reuse and recycling concepts. Such an indiscriminate use of concepts makes it difficult to identify state-of-the-art knowledge, and thus essential research areas, for facilitating exploitation of metal stocks accumulated in the technosphere.

This study reviews research dealing with concepts for mining the technosphere and aims to develop a taxonomy describing the full diversity of such metal recovery initiatives in terms of which stocks they address, the objectives for mining, level of realization, and what makes them different from other resource extraction and recycling concepts. In doing so, we first analyze the potential of

\footnotetext{
${ }^{1}$ Here, the technosphere is defined as material stocks established by human agency, and which as we shall see originate from technological processes, in contrast to stocks in the lithosphere established by slow, primary geological processes. 
different metal stocks as resource reservoirs, taking their size, concentration and spatial location in the technosphere into account. These metal stocks are then put in relation to research on mining the technosphere in order to identify overlaps or gaps regarding which stocks the reported concepts and initiatives address. Based on this analysis, a new taxonomy is developed involving six concepts for mining the technosphere, in which each concept addresses a specific type of metal stock. The new taxonomy is then applied to structure state-of-the-art knowledge and identify key challenges for facilitating realization of technospheric mining. In some cases, when reported initiatives for metal recovery are lacking in the reviewed literature, attention is also given to a somewhat wider definition of mineral recovery, e.g. including recovery of plastics.

\section{Metal stocks in the technosphere}

Methods of material flow analysis have been increasingly used to prospect and quantify metal resources present in the technosphere. These metabolism studies often identify six different types of technospheric stocks (e.g. the STAF project ${ }^{2}$ ): in-use stocks, landfills, tailing ponds, slag heaps, hibernating stocks, and dissipated metal resources, as illustrated in Figure 1. In addition, geological stocks in ores are often included in the material flow as this feeds all the other stocks. Accumulations of metals in the technosphere are commonly referred to as secondary metal resources, i.e., "those sources where metal is not in a form of a geological ore, having been manipulated to an extent by human action" (Rauch, 2009). The spatial distribution of such metal stocks is extensive, since humanmanipulated metals may accumulate anywhere human activity makes an impact, intentionally or not, from the deep sea all the way to space.

\footnotetext{
${ }^{2}$ The Stocks and Flows project at Yale University. For more information please visit: http://cie.research.yale.edu/stocks-and-flows [access: 2011-10-15]
} 

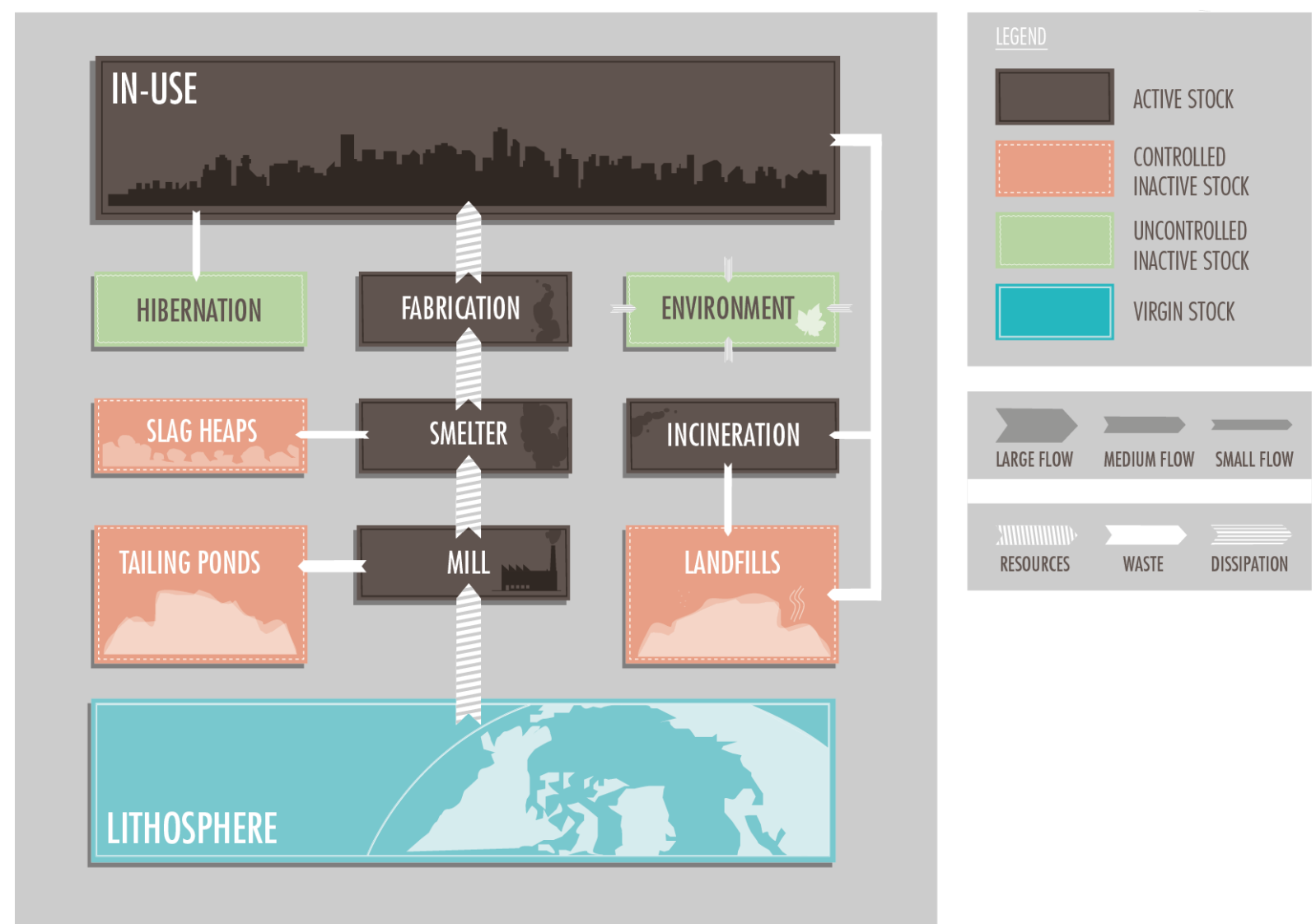

Figure 1. Diagram showing how metals from the lithosphere linearly accumulate in different stocks situated in the technospere. The magnitude of the flows are based on cycles of anthropogenic Iron (Wang et al., 2007; Kuo et al., 2007) and copper (Graedel et al., 2004; Kuo et al., 2007). From all stocks, secondary metals dissipate into the surrounding environment (land, sea, air or even space). Note that the figure is a simplification; for example, slag can originate from a smelter as well as be a residue from further pyrometallurgical processes.

On a general level, accumulation of metals within the technosphere can be categorized into active and inactive stocks. The active stock commonly involves all metallic goods in-use that currently have an owner and fulfill a function, encompassing smaller items that usually move rapidly through the use phase such as electronics, cans and batteries as well as larger objects and systems such as buildings and infrastructure that tend to persist in-use for decades (Spatari et al., 2005; van Beers and Graedel, 2007; Drakonakis et al., 2007; UNEP, 2010).

Inactive metals lack a function and are thus usually unwanted. Such stocks can furthermore be divided into controlled and uncontrolled inactive stocks. Controlled inactive stocks, such as landfills, tailing ponds or slag heaps, are usually the result of current waste management practices. Although efficient recycling programs have been implemented in some countries (UN-HABITAT, 2010), the majority of end-of-life products that are collected by waste management in the world still end up in landfills (Eurostat, 2009; Kollikkathara et al., 2009; UN-HABITAT, 2010). In countries like Sweden, where incineration has largely replaced landfilling, significant amounts of metals also end up in ash, which is commonly landfilled. While tailings are leftovers after the mill process and extraction of metals from ore, slag is a residue product from the refining of ore by pyrometallurgical processes such as smelting, converting, and refining. Tailings are commonly stored in ponds, but could also be backfilled into the mine (Grice, 1998) or stored in dry stacks (Davies and Rice, 2001).

Uncontrolled inactive stocks consist of accumulations of obsolete metals that have not been collected by waste management or other end-of-pipe solutions. Hibernation refers to parts of the in- 
use metal stock that over time have been permanently taken out of use without being collected for waste management (Bertram et al., 2002). These are, in other words, goods that still remain in their original locations but without any reasonable expectation of resuming their intended functions. Such hibernating metals can be found all over, for example, in your attic where obsolete electronic equipment may be stored (Kapur and Graedel, 2006) or in infrasystems such as old sewage systems, disconnected parts of power grids, decommissioned military structures (Krook et al., 2011) or other abandoned places such as ship graveyards (Richards, 1998). Dissipated metal resources (Kapur and Graedel, 2006) are not under the control of waste management, but in contrast to hibernating stocks, neither do they remain in their original location in the technosphere. Instead, such stocks represent the share of employed metals that has been dispersed to the surrounding environment (land, sea, air or even space), often due to friction or turbulence such as copper corrosion from roofs, metal leaching from landfills or zinc emissions from brake linings (Sörme et al., 2001a). Another type of dissipation is debris. While space debris primarily consists of abandoned space bodies (Liou and Johnson, 2006), marine debris tends to originate from human mishandling of discarded items such as waste escaping from landfills (Nollkaemper, 1994).

The boundaries between the technospheric stocks of minerals are fluid, however. For example, slag may in some cases be deposited next to household waste in a landfill. For that reason, in some cases the overall division of the stocks simply according to their state into active, inactive controlled and inactive uncontrolled may be more applicable. 


\subsection{Size, concentration and location}

In order to evaluate the potential for mining any kind of resource reservoir, information about its size, concentration, and location is fundamental (Hartman and Mutmansky, 2002; van Beers and Graedel, 2007; Brunner, 2007).

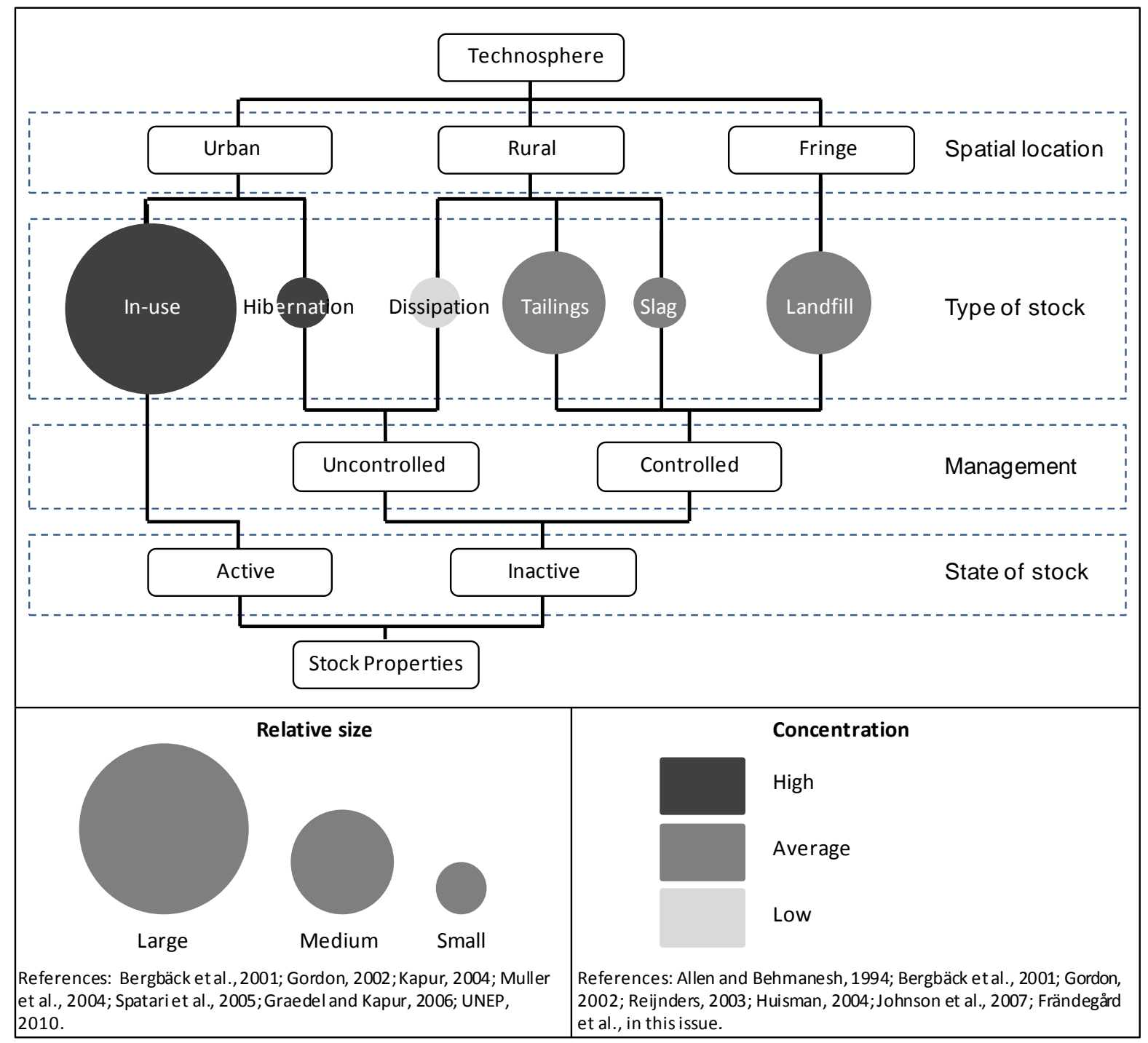

Figure 2. The stocks situated in the technosphere may generally be categorized according to size, concentration, primary location, and state of stock. This categorization is primarily relevant for copper and iron.

The size of technospheric metal stocks may be divided into three different magnitudes, as seen in Figure 2. Although there are quantitative estimations of in-use stocks for several metals (e.g. Gerst and Graedel, 2008; UNEP, 2010), only for iron and copper is there a comprehensive overview of the magnitude of different stocks in the technosphere, which in turn indicates the limitations of this comparison. For these metals, the largest stock is by far the current in-use stock, estimated to comprise at least $50 \%$ of the total amount of metal in the technosphere (Brunner and Rechberger, 2004; Spatari et al., 2005; Muller et al., 2006; UNEP, 2010). From a resource perspective, the size of the in-use metal stock is often significant. At present, for instance, the global in-use stock of copper corresponds to $50 \%$ of the virgin reserves remaining in known ores (Gerst and Graedel, 2008; USGS, 2010). Landfills and tailing ponds may be placed in a medium category, where approximately $10-20 \%$ of the technospheric metal resources are situated (Gordon, 2002; Brunner and Rechberger, 2004; Spatari et al., 2005; Muller et al., 2006). Slag heaps, hibernating stocks, and dissipated metal 
resources are considered to be even smaller sinks of metals, thus constituting a third size category accounting for about 1-5\% of technospheric metal stocks (Bergbäck et al., 2001; Gordon, 2002; Spatari et al., 2005; Kapur and Graedel, 2006; Muller et al., 2006). On a global scale, this pattern of secondary resource accumulation is likely to persist, since roughly similar shares enter the different stocks annually (Graedel et al., 2004; Wang et al., 2007). For metals under regulatory phase-out, such as mercury, it is likely however that the landfill stock will eventually exceed the stock in-use (UNEP, 2010).

The concentration or grade of metals within the technosphere may also be categorized into three magnitudes, as illustrated in Figure 2. Generally, the concentration of metals is highest in refined products, most of which is found in in-use or hibernating stocks. Mobile phones, for instance, can have a copper content of 5-15\% by weight (Huisman, 2004; Boliden, 2008) and power cables may have concentrations reaching above $30 \%$ of weight of copper (SwedEnergy, 2009). Several studies support that the typical concentration of metals in goods tends to be higher than in geological stocks in ores currently mined (Allen and Behmanesh, 1994; Johnson et al., 2007). In addition, tailing ponds, slag heaps, and landfills may constitute a second category of average metal concentrations, which in many cases are equivalent to the grade in ores currently mined. Tailings and slag are uneconomical leftovers after processing the ore, and the metallic concentration may vary greatly according to the efficiency of the applied technology and the original composition of the ore. According to Gordon (2002), the average copper content of tailings, for example, fell from about $0.75 \%$ to $0.14 \%$ during the 20th century. In the early 20th century, smelter slag typically contained about $0.35 \%$ copper (Hayward, 1952). Since then, however, the copper concentration has generally increased because of the adoption of the flash smelting method (Gordon, 2002). In Sweden, copper is currently mined at a profit from ore with a concentration of $0.37 \%$ copper by weight per ton (Boliden, 2008). The concentration of metals in landfills is uncertain and varies according to time and space, where landfills located near communities with high consumption of metals lacking sophisticated recycling systems tend to have higher contents. Ongoing research on landfill mining in Sweden estimates that a typical municipal landfill contains about 3.6\% iron and 0.3\% copper (Frändegård et al., 2012). In general, the stock of dissipated metal resources has a low concentration considering the high level of dispersal into surrounding water, air or soil (Bergbäck et al., 2001; Craig, 2001; Reijnders, 2003). Such dissipated metal stocks may thus be placed in a third category with low concentrations.

Statements based on concentration could however be problematic since metals tend to be distributed unevenly in technospheric stocks. The grade of a metal in virgin ore is usually determined by a sample extracted from the identified ore, for example, through a drill hole (Hartman and Mutmansky, 2002). In a similar way, ores with particularly high concentrations may be identified in the technosphere. Parts of landfills may for instance contain large quantities of isolated railroad tracks. In such specific areas, the metal concentration would obviously be extremely high. Metal stocks with high concentration could even be identified within a dissipation context. Marine debris has for example been reported to contain up to $10 \%$ by weight of metals (Moore et al., 2001), although plastic is the major element (Derraik, 2002). Space debris may contain up to 8.8 grams of copper $/ \mathrm{cm}^{3}$ and 7.9 grams of steel $/ \mathrm{cm}^{3}$ (Opiela, 2009).

Technospheric stocks may be further divided into three main locations: urban, rural, and something in between, called the "fringe," as shown in Figure 2. Refined products either in-use or in hibernation are primarily found where they are or have been used, which is mainly in urban areas (Ostrolenk, 1941; Jacobs, 1969). Van Beers and Graedel (2007) have, for instance, shown that the accumulation of in-use zinc and copper in Australian urban areas might be more than a hundred times higher than in rural areas. Specific systems such as regional power grids may, however, have a significantly higher share of hibernating metal resources in rural areas than in urban areas (Wendell, 2005). Other types of metals such as uranium and plutonium are often located at nuclear power plants far from human 
settlements (Graedel and Allenby, 2010). On a general level, controlled inactive stocks are located in more rural areas, since waste has traditionally been regarded as a local pollution problem and thus often relocated away from communities. Tailing ponds and slag heaps are typically situated close to mining operations, smelting plants, steel and stainless steel factories (Hayes, 2005). For landfills, the situation is somewhat different since urban sprawl has often extended to waste deposits that were formerly only in the general vicinity of cities. Finally, dissipated resources typically end up in the environment, for example, marine debris accumulating in oceanic gyres (Pichel et al., 2007).

\section{Mining the technospheric stocks}

\subsection{Existing mining concepts}

The most common concept used to describe recovery of mineral stocks in the technosphere is urban mining - a metaphor reaching far beyond the academic literature and commonly mentioned in media such as news, websites, and blogs. Urban mining has been defined in the scientific community as the recovery of secondary resources from technospheric stocks (Brunner and Rechberger, 2004; Wittmer and Lichtensteiger, 2007), as illustrated in Figure 3. It originally springs from the belief in a horizontal relocation process where the minerals in virgin mines flow from the wilderness (Giurco et al., 2009) toward urban areas, which become the largest sink for accumulated technospheric metals (Ostrolenk, 1941; Jacobs, 1969; Van Beers and Graedel, 2007). Accordingly, the concept of urban mining has been mentioned primarily in conjunction with technospheric stocks concentrated in urban areas, i.e., in-use stocks (Gerst and Graedel, 2008) and hibernating stocks (Krook et al., 2011). Mining above ground (UNEP, 2010) originates from the vertical relocation process of the resource base from below to aboveground (Kapur and Graedel, 2006), and probably includes, like urban mining, resource recovery from all technospheric stocks. Secondary metals are generally accessible for utilization when the metal resources have been categorized as waste, which could explain the concept waste mining (Ayres, 1999; Ayres et al., 2001). Ayres et al. (2001) use the concept in light of the new opportunities to recover metals from traditionally overlooked waste streams in the form of byproducts flowing toward landfills (coal ash) or tailings (red mud). Another emerging concept is secondary mining, associated with the reprocessing of leftovers after virgin minerals have been processed (Pirrone and Mahaffey, 2005; Hayes, 2005). Secondary mining is when more modern technology is applied to old tailing ponds (Pirrone and Mahaffey, 2005) or slag heaps (Tateda et al., 1997) with large content derived from inefficient milling or smelter techniques. Landfill mining has been defined by Cossu et al. (1996) as "the excavation and treatment of waste from an active or inactive landfill" ${ }^{\prime \prime}$. In the literature, landfill mining has been associated mainly with municipal landfills (Hogland et al., 1995; Hull et al., 2005), but also occasionally with sludge and slag heaps (Zanetti and Godio, 2006; Franke et al., 2010). The picture however is ambiguous. For example, the term urban mining is also used to conceptualize the recovery of overlooked waste streams such as e-waste (e.g. Oswald and Reller, 2011) as well as to describe virgin mining located in or near urban areas (e.g. Dayani and Mohammad, 2010). Secondary mining is also a term used in traditional mining to describe the recovery of pillars left behind in virgin mines to support roofs and prevent collapse (e.g., Ghasemi et al., 2010).

\footnotetext{
${ }^{3}$ In addition, there are variations to the presented mining concepts. For example, "enhanced landfill mining," targeting complete valorization of materials and energy from past, present and future landfills using innovative technologies (Hogland et al., 2010).
} 


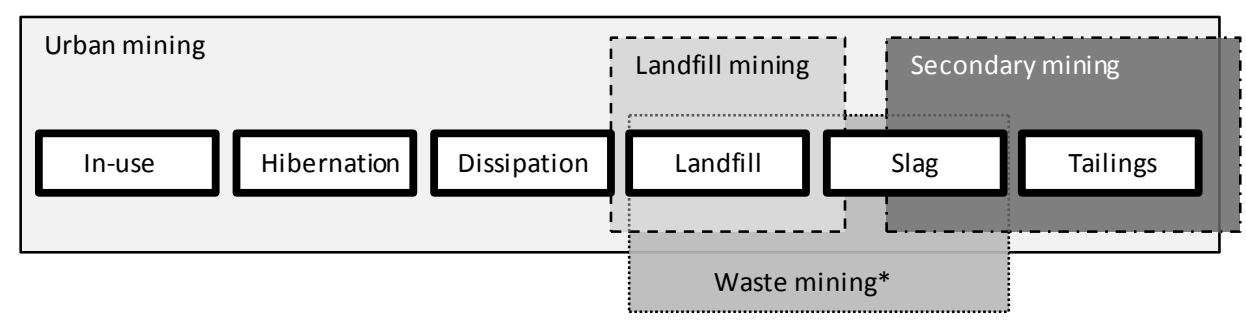

*Waste mining focuses on the flow towards these stocks.

Figure 3. Existing mining concepts and their connection with different stocks in the technosphere.

\subsection{The taxonomy of technospheric mining}

Existing mining concepts fail to help us navigate reliably in the complex technosphere, since they are disorganized, as seen in Figure 3 , and a clear categorization has not yet taken form. First of all, the concepts overlap one another when it comes to which stocks they address, which is especially true for controlled inactive stocks, e.g., landfills, slag heaps, and tailing ponds. Two of the concepts, i.e., secondary mining and urban mining, are commonly used within the terminology of virgin mining. The definitions of the concepts are also vague and problematic. As previously noted, a number of technospheric stocks are primarily located away from urban areas, undermining the universal nature of the "urban" mining concept. Besides, extraction of some types of secondary metals, such as metals in subterranean infrasystems, may prove to be more profitable in rural than urban areas (Krook et al., 2011). Furthermore, while some existing concepts (urban mining and landfill mining) embrace all secondary resources present in the technosphere and landfills, other concepts (waste mining and secondary mining) focus exclusively on minerals or metals. Consequently, the prevailing concepts, primarily urban mining and waste mining, are intertwined with traditional waste management to describe the recovery of metals from waste flows. The vagueness and fluidity of these concepts makes it difficult to clearly identify and explain state-of-the-art knowledge and what makes metal recovery from technospheric stocks different from primary resource extraction and traditional waste management.

In order to facilitate such an examination, a new and more stringent taxonomy is needed, which takes the differences in size, concentration, location and accessibility among technospheric stocks into account. However, we also believe that the mining metaphor is valuable since when properly used it maintains the potential for "eye-opening" solutions. For instance, this metaphor perceives metal accumulations in the technosphere as important assets rather than solely as hazardous or a problem. Although the waste sector to an increasing extent regards waste as a resource, waste management still focuses on pollution prevention (e.g. European Council, 1991) and efficient disposal (e.g. OECD, 1994). Mining is the extraction of specific metals in response to market demand, while waste management is commonly mandated by law (e.g. European Council, 1991) to manage all discarded materials, whether organic or hazardous. Above all, the mining metaphor brings a particular focus on the management of stocks rather than on handling of waste flows. Such an approach spans the whole technosphere, embracing previously untapped reservoirs of metals, beyond the limited focus on in-use stocks successively turning into waste. Besides, if metals are defined as waste, their recovery is never certain; they may as well for example be deposited together with the generated ash after incineration.

Technospheric mining seems to be a suitable term to describe extraction and recovery of mineral stocks within the technosphere in contrast to traditional virgin mining, since it brings all humangenerated stocks into consideration. Technospheric stocks, however, are more or less ubiquitous since secondary metals are present in numerous forms (molecules of copper in air emissions as well as large steel constructions in-use), and are limited only by human ingenuity. Their location may 
furthermore be deep below the earth in terms of copper cables, in attics as obsolete mobile phones, or in space in the form of satellites. This implies that accessibility, suitable extraction methods, research needs, and the current level of implementation for extraction of metals in the technosphere can change substantially. The umbrella is therefore split into different subtypes correlating to stocks situated in the technosphere, suggesting six different subgroups within the umbrella of technospheric mining, as illustrated in Figure 4.

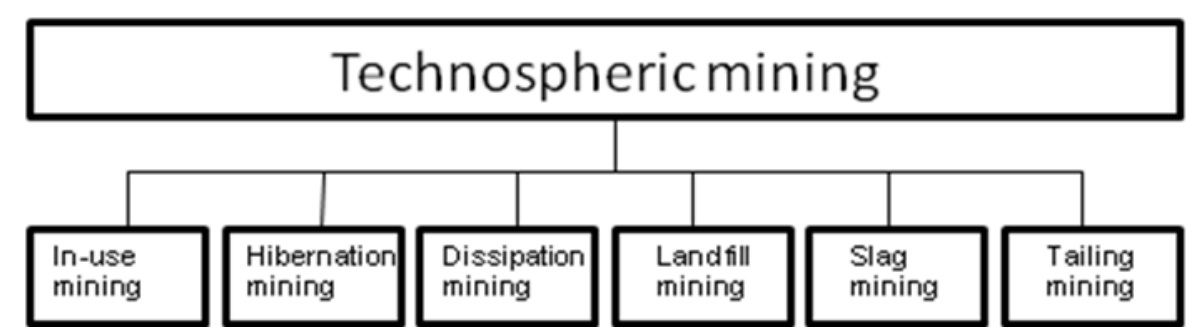

Figure 4. Technospheric mining is suggested as an umbrella concept for extraction of technospheric stocks of minerals. However, secondary metals occur in many different forms and therefore require disaggregated analysis, divided according to how stocks are situated in the technosphere.

\section{Technospheric mining}

As stated above, the notion of mining has a focus on stocks rather than flows and on the perception of stocks as resources. Hence, identifying the stocks becomes a key issue within this field or what could be termed technospheric prospecting. Another key issue becomes the extraction of metals from the stock, i.e., the mining operation itself. However, when the mineral has been extracted, for example from a landfill, the mineral is nevertheless most likely material recycled in order to restore the raw material for later use. Furthermore, the line between stocks and flows is fluid; there are, for example, stocks in processing facilities (UNEP, 2010) with short-term storage of metals. These types of stocks are however part of ongoing material loops and can therefore not reasonably be extracted. Instead, technospheric mining refers to the extraction of technospheric stocks of minerals that have been excluded from ongoing anthropogenic material flows. This also concerns stocks under the control of waste management systems such as landfills, which is a typical example of a sink.

\section{Subtype 1: In-use mining}

The research on in-use stocks from a mining perspective has considered the low accessibility due to ownership and fulfilling a purpose primarily focused on prospecting specific metals of strategic importance by mapping the location (van Beers and Graedel, 2007), composition (Johnson et al., 2007), lifetime (Sparati et al., 2005), and specifically the size of stock (Gerst and Graedel, 2008; Du and Graedel, 2011). The aim has been to provide a vision of what may come. Formal large-scale recovery of metals in-use is unusual, as illustrated in Figure 5. There are, however, rare exceptions. In-use mining could be referred to as strategically relocating metals already in-use due to changed market conditions, where metals, despite their ownership and present purpose, are moved toward more needed purposes. Hence, it represents an aberrational subtype of technospheric mining, where the activity leads to excluding metals from the regular material flow, rather than utilizing already excluded metals. Klinglmair and Fellner (2010) have described examples of in-use exploration when the Austrian Empire tried to accelerate the flow of secondary metals to secure the resource supply of war metals during World War I. Although harsh methods such as confiscation were used, only $10 \%$ of the stock in-use was made available. 


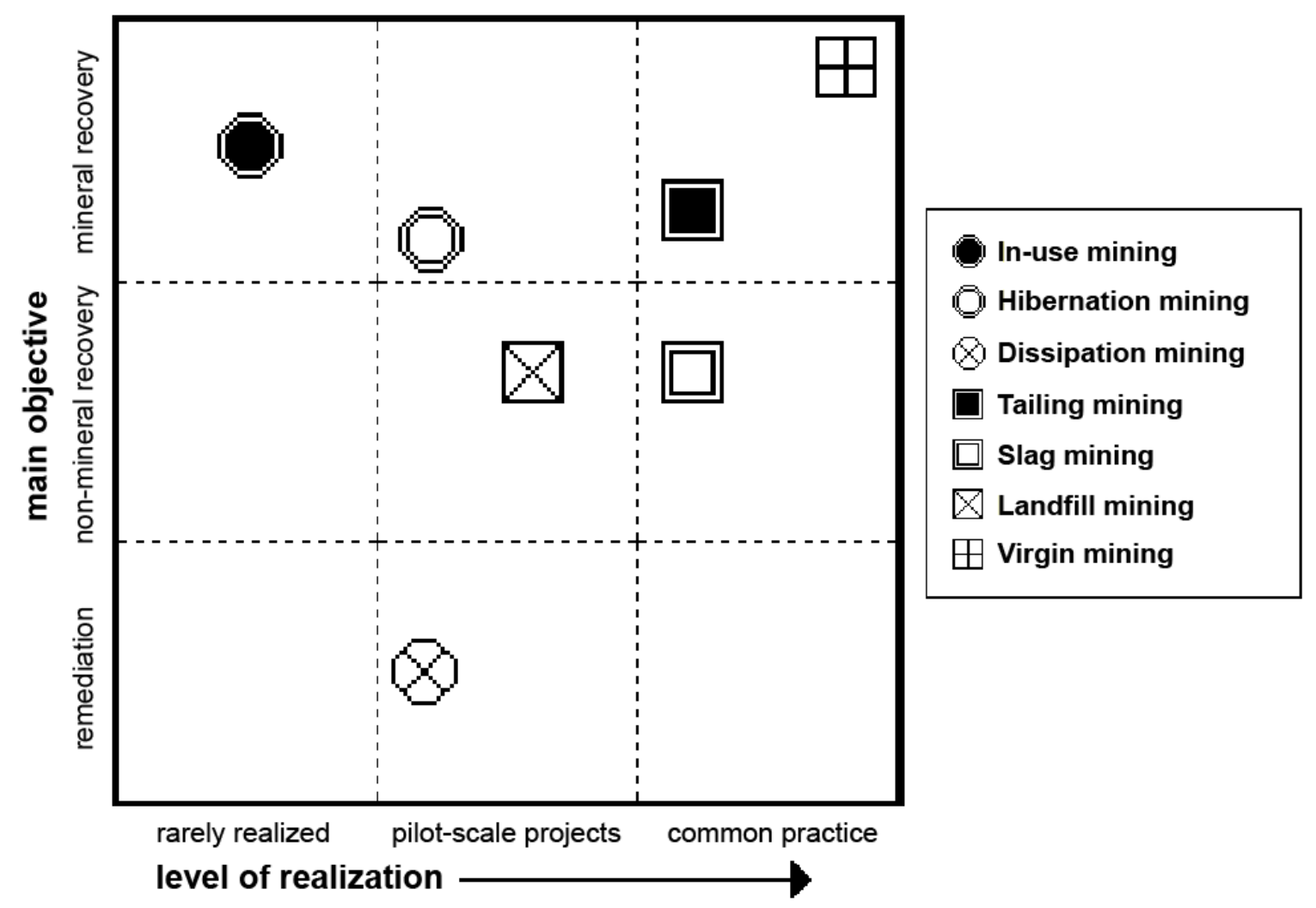

Figure 5. The primary drivers for technospheric mining in its various subtypes and traditional virgin mining differ. Generally, there are three driving forces behind the extraction of technospheric stocks of metals. Remediation removes and sometimes utilizes metal stocks, since the presence of metals poses an environmental threat. During non-mineral recovery the excavation is driven by other purposes, for example providing exhumed metal resources for building purposes such as road construction. In some cases, metal stocks are excavated to access the raw material. The placement of each subtype is further explained in the text.

\section{Subtype 2: Landfill mining}

Detailed descriptions of formal landfill mining projects that have been realized on a large scale are rare (Krook et al., 2010), although such projects are nevertheless under consideration (e.g. Jones et al., 2010). Pilot projects exploring the feasibility of mining specific deposits are, however, quite common throughout the world (e.g. Savage, 1993; Cossu et al., 1996; Hino et al., 1998; Kurian et al., 2003), as seen in Figure 5. According to Krook et al. (2010), extraction of landfills has primarily been hailed as an innovative strategy to solve traditional waste management issues such as lack of landfill space (Dickinson, 1995), facilitation of final closure (Richard et al., 1996) or remediation of waste deposits (Hogland et al., 1995). Although most initiatives have involved some effort to recover deposited resources (primarily cover soil material), such constituents have been largely secondary. Landfills may be available for resource recovery since they are inactive, but any existing metals are disorganized and placed together with other types of waste, making the landfill a kind of "black box." Obviously, the focus of landfill mining to date has concentrated on composition (Hogland et al., 1995; Kurian et al., 2007) and technology for excavation (Cobb and Ruckstuhl, 1988; Chang and Cramer, 2003). 


\section{Subtype 3: Tailing mining}

Extraction and recovery of tailings most commonly occur for gold (Bugnosen, 2001), copper (EPA, 1993a) or iron (Karlberg, 2010). In 1994, $250 \mathrm{Gg}$. copper, corresponding to $2 \%$ of the global production of copper, was derived from reworked tailings (Graedel et al., 2004). Tailings are in general more homogenous compared to landfills including iterative residues from one actor. Research on tailings utilization has focused both on composition (Clevenger, 1990) and methods for extraction (Benn and Cornell, 1993). However, past as well as recent failures (ICOLD, 2001), not least the Hungary tailings spill disaster (Kosich, 2010), have increasingly put focus on the safety of tailings impoundments. Reprocessing of tailings has thus been highlighted as an innovative reclamation technology, for example for treatment of uranium (Smith, 2006), pyrite and other silicate tailings (Jenning and Kreuger, 1997). In addition, to reduce the need for deposition, tailings have been reported to be a suitable material in paint (Saxena and Dhimole, 2006), cement (Yi et al., 2009) or construction bricks (Chen et al., 2011).

\section{Subtype 4: Slag mining}

Recovery of metals from slag heaps of copper (EPA, 1993b) and steel (Stepanov and Romanenko, 1997) has been reported, but in general to a lower extent compared to tailings. Slag heaps are often homogenous and from one actor. But the metals situated in the slag are more difficult to leach out than, for example, from tailings, since they are commonly tightly bound or enclosed in sintered or glass materials (Engström, 2010). Therefore, slag is commonly used in downcycling applications, as a resource in road construction (Lind et al., 2001), landfill cover (Diener et al., 2007) or in more valued applications such as cement production (Davidovits, 2011). In Europe, for example, during 20081.3 million tons of ferrous slag were excavated from heaps to fulfill building purposes such as road construction (Bialucha et al., 2011). The research focus has been on composition studies (Richardson et al., 1994; Gorai et al., 2002) and methods on a laboratory scale for extracting the metals from slag (Wilson et al., 2006; Brocchi and Moura, 2007).

\section{Subtype 5: Hibernation mining}

Recovery of abandoned metals, not yet collected by waste management, is uncommon, as illustrated in Figure 5. For example, inactive subterranean infrasystems are seldom taken care of, with rare exceptions when recovery is combined with maintenance work on systems located in the same space (Krook et al., 2011). Otherwise, the inactive infrasystem tends to be left untouched, for example, cost reasons or due to limited knowledge. In general, our understanding of hibernating metal resources is low; rare exceptions include publications by Chan (2004) and Krook et al. (2011) on prospecting hibernating household products and infrasystems. Several innovative companies (e.g.

envirofone.com) offer cash for household goods such as mobile phones. Although this could be regarded as traditional attraction for end-of-use products, it may also provide an incentive to return obsolete mobile phones.

\section{Subtype 6: Dissipation mining}

Dissipated stocks are commonly considered unrealistic to utilize (Craig, 2001; Reijnders, 2003; Jeong et al., 2009) since secondary metals have literally dissipated back into the environment, and with the consequence of uncertain location and low concentrations in sea, land, and air (Bergbäck et al., 2001). Dissipated stocks, therefore, are seldom recovered. However, dissipation mining could in theory lead to metal recovery from storm water, including dissipated zinc washed away from the asphalt by rain water. Removal of dissipated material primarily in the form of space and marine debris has attracted attention as a way to avoid potential problems (Williamson, 1991; Liou and Johnsson, 2006; Moore, 2008), as seen in Figure 5. Pilot projects focusing on cleaning up marine debris have been conducted by NGOs such as the Environmental Cleanup Coalition ${ }^{4}$ and Project

\footnotetext{
${ }^{4}$ For more information see: http://www.gyrecleanup.org/ [access: 2011-10-31] 
Kaisei, ${ }^{5}$ multinational company initiatives such as Vac from the $S e a^{6}$ as well as governmental collection on a regular basis (Cho, 2009). The primary focus of cleaning up debris has been reclamation, but the collected recourses will in some cases be recovered. Electrolux is developing new concept vacuum cleaners (Ridden, 2010), while Kaisei is planning to test experimental recycling such as converting plastic waste to fuel (Regan, 2010). For space debris, proposed methods for mitigation, such as large balloon-like devices (Williamson, 1991), a huge fishing net (Bonnal and Alby, 2000), a force-controlled space robot arm (Nishida and Kawamoto, 2011), or a ground-based laser system (Phipps et al., 1996) are not yet technically feasible or economically viable (Crowther, 2002; Liou and Johnson, 2006).

\section{Challenges for technospheric mining}

For virgin mining, a huge ore reserve with high metal concentration located close to markets is the ideal situation. The prospects for technospheric mining are, however, somewhat different. For example, all these conditions are fulfilled for in-use mining, but in-use products such as mobile phones have low or almost zero accessibility, since the owners are commonly satisfied with the current purpose. Although inactivity over time brings another kind of problem since metal resources may lose in quality, become uncontrolled or forgotten, they are at least directly available on demand. The inactive stock with highest concentration is probably the hibernating stock, consisting mainly of refined products, while these types of inactive metals are also commonly located close to markets. Close to market is not always an advantage, however; mining activity, for example, may pose concerns over health and the environment in terms of vibration, noise, odor and leaching, complicating the application for a permit needed to implement mining activities. Hibernating metals as well as in-use metals (Sörme et al., 2001b) and dissipated metal resources (Sörme et al., 2001a) are also highly dispersed and specific positions largely unknown, which places high demands on the collection system. If, in addition, the distribution of the metals is uncontrolled, the ownership can be difficult to determine (Nollkaemper, 1994; Bradley and Wein, 2009). All in all, this brings focus to controlled inactive stock such as landfills, tailings ponds, and slag heaps. Although these stocks have lower concentrations than refined goods, the amount of metals clustered in one place puts lower demands on the organization needed for extraction according to the principles that make virgin mining profitable, i.e., economy of scale.

However, it is not only the concentration, size, state of stock or grade of disparity that determines the potential for mining; the social-technical context will also influence the potential. Tailings have many similarities to virgin ores including characterization, methods for extraction, ownership and actors involved, which probably explains why tailing mining commonly occurs. Other types of technospheric mines are generally under the ownership of actors with no experience or knowledge of extraction and recovery. Even landfill owners aware of mining as an opportunity probably do not have sufficient knowledge to operate such a project. Virgin mining is furthermore commonly executed by specialists, including everything from geologists to economists ready to invest in necessary learning processes. This learning process stalls if the initiatives are executed by scattered owners of, for example, landfills or hibernating infrasystems. Hence, to move toward common practice, actors specialized in technospheric mining are needed. Great demands will be put on them however due to the heterogeneity of technospheric metals. A well-defined area such as a landfill may encounter everything from metals in molecular form in ash to large metal objects. When prospecting a landfill, given the level of detail required, an archeologist prospecting the landfill is probably more suitable than a geologist (for examples, see Rathje and Murphy, 1992).

\footnotetext{
${ }^{5}$ For more information see: http://www.projectkaisei.org/ [access: 2011-10-31]

${ }^{6}$ For more information see: $\mathrm{http} / / /$ www.electrolux.se/Innovation/Campaigns/Vac-from-the-sea/ [access: 201110-31] 
Although specialized actors are needed, technospheric mining will still probably involve a wide range of actors: one who owns the technospheric metal resources, another with the ability to collect and separate out the metals, and a third that has the capacity to recover the metal. Additional actors, for example, engineers/researchers who develop appropriate technology and identify critical factors for implementation, are crucial as well. Local residents and authorities should also be included, considering that mining will likely affect the local environment. Hence, consortiums (Craps and Sips, 2010) or other types of collaborative platforms, where all the actors can interact and share experiences, are needed.

The heterogeneity of technospheric mines in characterization, location, form, actors, and technology also places demands on flexibility through regulations and laws. Today regulation, taxes and permission are often adapted to linear flows. Landfill bans and taxes may, for example, prevent redepositing of excavated undesirable materials. Furthermore, throughout the Western world landfills are often capped in response to landfill regulation (e.g., European Council, 1999), which could make the owner resistant to opening it for mining. Capping a mine, which typically is the last step in conventional mining (Hartman and Mutmansky, 2002), and other types of linear regulations raise the importance of governmental agencies to recognize types of circulation (read: technospheric mining) other than traditional recycling in vital decisions.

Research on extraction methods and composition of technospheric stocks is of continued interest. Such knowledge is necessary for any mining activity, but at the same time, it denies the true complexity of technospheric mining. Mining the technosphere is probably more common than we at first imagine. Below the radar of formality, informal recovery and extraction of different technospheric stocks are most likely common practice. A typical example is metal thieves stealing inuse as well as hibernating metals for their extrinsic value as raw material, triggered by rising prices and demand for scrap (Sidebottom et al., 2011). Metal theft has been cited as a growing problem ${ }^{7}$. Reports have demonstrated that almost all metal objects run the risk of being stolen, even if the object is located in inhospitable surroundings such as the Chernobyl disaster zone (Melnik, 2004). Scavengers at landfills are also common in many parts of the world (e.g. Rankokwane and Gwebu, 2006). Within the informal sector, there are probably lessons to learn as well as to explore. Although ownership and formal agreements could make such an approach controversial, the informal sector can nevertheless teach us how to change our perception of technospheric stocks, and view them not as a problem but as a resource.

\section{Two ways forward for technospheric mining}

There are two main drivers for technospheric mining: environmental and economic factors in varying degrees. In cases where landfill or dissipation mining is addressed as an innovative solution in remediation projects to secure the environment in a certain area, recovery of metals may offer additional revenue at the same time. In cases where tailing mining is driven by profit, environmental benefits, in the form of avoidance of latent leakage or saved virgin metals, may become an additional contribution to goodwill. Although this overlap probably will remain, either economic or environmental drivers are likely to propel technospheric mining.

Traditional mining of virgin minerals is clearly driven by profitability with an explicit focus on minerals as raw material (Hartman and Mutmansky, 2002). Hence, mining has traditionally been realized by self-organizing individual companies in the private sector. Analogously, extraction of metals situated

\footnotetext{
${ }^{7}$ A study of insurance databases by Whiteacre and Howes (2009) showed that Detroit for example had 271 metal theft claims per 100,000 residents. 
in technospheric stocks may become increasingly profitable. Hence, technospheric mining could be driven bottom-up by mining companies that perceive technospheric stocks as a valuable resource. For example, development of technology could make previously unattractive concentrations and accessibilities interesting, similar to the technology push in traditional mining and the case of deep sea mining (Halfar and Fujita, 2002). New business models could also be adopted in which income and expenses are shared, for example, between the owner, collector, and recycler (Baas et al., 2010). Other resources obtained from the excavation may also add income such as combustibles in a landfill or selling the rehabilitated land. Projects could also be evaluated through the societal costs of the consequences of not conducting mining activity, for example, the cost of not extracting a landfill (van Passel et al., 2010) or collecting marine debris. A future where fishing boats collect marine debris profitably, instead of overfishing the sea, is an appealing scenario. This has been tested by societies realizing the actual cost of uncontrolled marine debris, specifically in South Korea based on governmental funding (Cho, 2009).

Technospheric mining initiatives are currently often driven by environmental reasons, or in other words primarily executed to "save" the environment. Relative concentrations of metals within the technosphere, if situated in the wrong surroundings such as near ground water, may be an alarming problem. To prevent this problem, landfills, slag heaps, and tailing ponds can be mined. Such an approach, with roots in the perception of technospheric stocks as a problem, would probably be driven top-down by environmental or health regulation, forcing ownership of and responsibility for metal stocks. At a first level of an analysis, it is reasonable to assume that realization of technospheric mining on a broader scale can only become a reality if coupled with profitability. History, however, has shown that environmental drivers for recovery of secondary metals and topdown decisions might be a potential starting point. Traditional recycling was initially a response to the lack of new landfill space forcing recirculation (UN-HABITAT, 2010), but has today evolved into a flourishing industry and a major source of secondary metals ${ }^{8}$. At the same time, research concentrated on reclamation may also be beneficial for recovery projects and vice versa, since experiences with technology, composition, and regulations could in some cases be shared regardless of driving forces.

\section{Conclusion}

Extraction of metals from stocks accumulated in the technosphere will probably become more important in the years to come. This emerging field of knowledge is however still largely immature in the sense that a number of concepts and terms occur in the literature without being distinctly defined. This lack of definition makes it hard to delineate this field from other fields of research and knowledge, and obscures the special challenges and focused research needed to facilitate technospheric mining. For instance, it could be questioned whether the current use of urban mining in relation to metal recovery from e-waste flows involves something significantly new or if it is just a more up-to-date term for research dealing with the traditional challenges of improved waste collection and recycling.

Although a more refined taxonomy in itself will obviously not solve the challenges facing technospheric mining, it has proved useful for identifying significant differences in state-of-the-art approaches when it comes to different types of such mineral recovery. Applying the taxonomy in future research will thus facilitate identification and comparison of similar studies dealing with mineral recovery from technospheric stocks - a fundamental need for building a common knowledge base and thus a more stringent and progressive research field.

\footnotetext{
${ }^{8}$ In 1994, for example, $2.6 \mathrm{Tg}$ of copper was recycled globally, corresponding to $15 \%$ of the global production of copper (Graedel et al., 2004). 
This taxonomy could also be seen as a way to distinguish technospheric mining initiatives from traditional mining as well as waste management and recycling concepts. Doing so is essential as this type of mineral recovery, apart from traditional drivers and barriers for improved waste management, also is related to additional challenges, originating from the fact that the minerals occurring in technospheric stocks involve different characteristics in terms of size, metal concentration, location, accessibility and level of disparity. Being absolutely clear about such differences in future research seems fundamental. Otherwise, there is an obvious risk that we will fail to even identify the unique technical, economic, organizational and legislative challenges facing this emerging field of technospheric mining.

\section{Acknowledgements}

Financial support was provided by the Swedish Innovation Agency, VINNOVA and the Swedish Research Council for Environment, Agricultural Sciences and Spatial Planning, FORMAS.

\section{References}

Allen, D.T. and N. Behmanesh (1994) Wastes as Raw Materials. In D.T. Allenby and D. J. Richards (eds.), The Greening of Industrial Ecosystems, pp. 69-89. Washington, DC: National Academy Press.

Ayres, R. (1999) The second law, the fourth law, recycling, and limits to growth. Ecological Economics 29: 473-484.

Ayres, R., U.J. Holmberg and B. Anderson (2001) Materials and the global environment: Waste mining in the 21st century. MRS Bulletin 26: 477-480.

Baas, L., J. Krook, M. Eklund and N. Svensson (2010) Industrial ecology looks at landfills from another perspective. Regional Development Dialogue 31 (2): 169-183.

Benn, F.W. and W.L. Cornell (1993) Removal of Heavy Metals from Missouri Lead Mill Tailings by Froth Flotation. Separation Science and Technology 28 (1-3): 733-746.

Bergbäck, B., K. Johansson and U. Mohlander (2001) Urban metal flows - A case study of Stockholm. Water, Air and Soil Pollution 1: 3-24.

Bertram, M., T.E. Graedel, H. Rechberger and S. Spatari (2002) The contemporary European copper cycle: waste management subsystem. Ecological Economics 42: 43-57.

Bialucha, R., T. Merkel and H. Motz (2011) European environmental policy and its influence on the use of slag products. In P.T. Jones, Y. Pontikes, J. Elsen et al. (eds.) Proceedings of the Second International Slag Valorisation Symposium: The transition to Sustainable Materials Management [online] http://www.slag-valorisation-symposium.eu/images/papers/s3 3 motz.pdf [access: 2011-10-11].

Boliden (2008) Sustainability Report 2007. Boliden AB, Sweden.

Bonnal, C. and F. Alby (2000) Measures to reduce the growth or decrease the space debris population. Acta Astronautica 47 (2-9): 699-706.

Bradley, A.M. and L.M. Wein (2009) Space debris: Assessing risk and Responsibility. Advances in Space Research 43: 1372-1390.

Brocchi, E.A. and F.J. Moura (2007) Chlorination methods applied to recover refractory metals from tin slags. Minerals Engineering 21 (2): 150-156.

Brunner, P.H. and H. Rechberger (2004) Practical Handbook of Material Flow Analysis. Boca Raton: Lewis Publishers.

Brunner, P.H. (2007) Reshaping urban metabolism. J. of Industrial Ecology 11 (2): 11-13.

Bugnosen, E. (2001) Country Case Study on Artisanal and Small-scale Mining: Philippines. MMSD [online] http://pubs.iied.org/pdfs/G00732.pdf [access: 2011-10-31]. 
Chan, M. (2004) Hibernating Copper in Connecticut Residences and Corporations. Master's Thesis, School of Forestry and Environmental Studies, Yale University, New Haven, CT.

Chang, S. and R. Cramer (2003) The potential for reduction of landfill waste by recycling and mining of construction and demolition waste at the White Street Landfill, Greensboro, North Carolina. J. of Solid Waste Technology and Management 29: 42-55.

Chen, Y., Y. Zhang, T. Chen, Y. Zhao and S. Bao (2011) Preparation of eco-friendly construction bricks from hematite tailings. Construction and Building Materials 25 (4): 2107-2111.

Cho, D.-O. (2009) The incentive program for fishermen to collect marine debris in Korea. Marine Pollution Bulletin 58 (3): 415-417.

Clevenger, T.E. (1990) Use of sequential extraction to evaluate the heavy metals in mining wastes. Water, Air and Soil Pollution 50: 241-254.

Cobb, C.E. and K. Ruckstuhl (1988) Mining and reclaiming existing sanitary landfills. Proceedings of the National Waste Processing Conference, Detroit, MI, USA: 145-151.

Cossu, R., W. Hogland and E. Salerni (1996) Landfill mining in Europe and the USA. ISWA Tear Book: 107-114.

Craig, P.P. (2001) Energy limits on recycling. Ecological Economic 36: 373-384.

Craps, M. and K. Sips (2010) Enhanced Landfill Mining as a governance challenge: managing multiple actors, interests and perspectives. In P.T. Jones and Y. Tielemans (eds.) Enhanced Landfill Mining and the transition to Sustainable Materials Management, pp. 265-278. Houthalen- Helchteren; Haletra.

Crowther, R. (2002) Space Junk-Protecting Space for Future Generations. Science 296: 123 - 321.

Davidovits, J. (2011) Application of Ca-based geopolymer with blast furnace slag, a review. In P.T. Jones, Y. Pontikes, J. Elsen et al. (eds.) Proceedings of the Second International Slag Valorisation Symposium: The transition to Sustainable Materials Management [online] http://www.slagvalorisation-symposium.eu/images/papers/s1 1 davidovits.pdf [access: 2011-10-21].

Davies, M.P. and S. Rice (2001) An alternative to conventional tailing management - "dry stack" filtered tailings. AMEC Earth and Environmental, Vancouver, British Columbia, Canada.

Dayani, M. and J. Mohammad (2010) Geostatistical Assessment of Pb, Zn and Cd Contamination in Near-Surface Soils of the Urban-Mining Transitional Region of Isfahan, Iran. Pedosphere 20(5): 568-577.

Derraik, J.G.B. (2002) The pollution of the marine environment by plastic debris: a review. Marine Pollution Bulletin 44: 842-852.

Dickinson, W. (1995) Landfill mining comes of age. Solid Waste Technologies 9: 42-47. Diener, S., L. Andreas, I. Herrmann, H. Ecke and A. Lagerkvist (2010) Accelerated carbonation of steel slags in a landfill cover construction. Waste Management 30 (1): 132-139.

Du, X. and T.E. Graedel (2011) Global In-Use Stocks of the Rare Earth Elements: A First Estimate. Environment Science Technology 45 (9): 4096-4101.

Drakonakis, K., K. Rostkowski, J. Rauch, T.E. Graedel and, R.B. Gordon (2007) Metal capital sustaining a North American city: Iron and copper in New Haven, CT. Resources, Conservation and Recycling 49: $406-420$.

Elshkaki, A., E. van der Voet, M. van Holderbeke and V. Timmermans (2004) The environmental and economic consequences of the developments of lead stocks in the Dutch economic system. Resources, Conservation and Recycling 42: $133-154$.

Engström, F. (2010) Mineralogical influence on leaching behaviour of steelmaking slags a laboratory investigation. PhD Dissertation, Luleås Tekniska Högskola.

EPA (1993a) Tailings reprocessing: Magma copper company's Pinto Valley facility. U.S. Environmental Protection Agency [online] http://www.p2pays.org/ref/15/14369.pdf [access: 2011-10-31].

EPA (1993b) Slag reprocessing: Magma copper company's San Manuel facility. U.S. Environmental Protection Agency [online] http://www.p2pays.org/ref/18/17052.pdf [access: 2011-10-31].

European Council (1991) Council Directive 75/442/EEC modified by Directive 91/156/EEC on waste. European Council (1999) Council Directive 1999/31/EC of 26 April 1999 on the landfill of waste. 
Eurostat (2009) Waste generated and treated in Europe. Office for Official Publications of the European Communities, Luxembourg.

Franke, M., M. Mocker and M. Faulstich (2010) Resource Potential of Landfill Mining - A National and Regional Evaluation. ISWA World Congress, 15th-18th November 2010 [online] http://www.iswa.org/uploads/tx iswaknowledgebase/Mocker.pdf [access: 2011-10-31].

Frosch, R.A. and N.E. Gallopoulos (1989) Strategies for manufacturing. Scientific American 261 (3): 144-152.

Frändegård, P., J. Krook, N. Svensson and M. Eklund (2012) Developing a tool for environmental evaluation of landfill mining initiatives. J. of Cleaner Production, this issue.

Gerst, M.D., and T.E. Graedel (2008) In-use stocks of metals: status and implications. Environmental Science and Technology 42: 7038-7045.

Ghasemi, E., K. Shahriar and M. Sharifzadeh (2010) A new method for risk assessment of pillar recovery operation. Safety Science 48 (10):1304-1312.

Gorai, B., R.K. Jana and Premchand (2002) Characteristics and utilisation of copper slag-a review. Resources, Conservation and Recycling 39 (4): 299-313.

Gordon, R.B. (2002) Production Residues in Copper Technological Cycles. Resources, Conservation and Recycling 36: 87-106.

Graedel, T.E., D. van Beers, M. Bertram, K. Fuse, R.B. Gordon, A. Gritsinin, A. Kapur, R. Klee, R. Lifset, L. Memon, H. Rechberger, S. Spatari and D. Vexler (2004) The multilevel cycle of anthropogenic copper. Environmental Science and Technology 38: 1253-1261.

Graedel, T.E. and B.R. Allenby (2010) Industrial Ecology and Sustainable Engineering. New Jersey: Prentice Hall.

Grice, T. (1998) Underground mining with backfill. The $2^{\text {nd }}$ annual summit-mine tailings disposal systems, Australia.

Giurco, D., T. Prior, M. Gavin, L. Mason and J. Behrisch (2009) Peak minerals in Australia: a review of changing impacts and benefits. Prepared for CSIRO Minerals Down Under Flagship, by the Institute for Sustainable Futures (University of Technology, Sydney) and Department of Civil Engineering (Monash University), March 2010.

Halada, K., K. Ijima, M. Shimada and N. Katagiri (2009) A possibility of urban mining in Japan. J. of Japan Institute of Metals 73: 151-160.

Halfar, J. and R.M. Fujita (2002) Precautionary management of deep-sea mining. Marine Policy 26: 103-106.

Hartman, H.L. and J.M. Mutmansky (2002) Introductory Mining Engineering. 2d ed. New York; John Wiley \& Sons.

Hayes, B. (2005) Infrastructure: A field guide to the industrial landscape. New York; W. W. Norton \& Co. Ltd.

Hayward, C.R. (1952) An outline of metallurgical practice, 3d ed. New York: Van Nostrand.

Hino, J., Y. Miyabayashi and T. Nagato (1998) Recovery of nonferrous metals from shredder residue by incinerating and smelting. Metallurgical Review of MMIJ (Mining and Metallurgical Institute of Japan) 15: 63-74.

Hogland, W., K. Jagodzinski and J.E. Meijer (1995) Landfill mining tests in Sweden. Proceedings Sardinia '95, Fifth International Landfill Symposium, Cagliari, Italy, pp. 783-794.

Hogland, W., M. Hogland and M. Marques (2010) Enhanced Landfill Mining: Material recovery, energy utilisation and economics in the EU (Directive) perspective. In P.T. Jones and Tielemans, Y. (eds.) Enhanced Landfill Mining and the transition to Sustainable Materials Management, pp. 209222. Houthalen- Helchteren; Haletra.

Huisman, J. (2004) QWERTY and Eco-Efficiency analysis on cellular phone treatment in Sweden - The eco-efficiency of the direct smelter route versus mandatory disassembly of Printed Circuit Boards. Stockholm: El-Kretsen.

Hull, R.M., U. Krogmann and P.F. Strom (2005) Composition and Characteristics of Excavated Materials from a New Jersey Landfill. J. of Environmental Engineering 131: 478-490. 
ICOLD (2001) Tailings dams - risk of dangerous occurrences, lessons learnt from practical experiences. United Nations Environmental Programme (UNEP) Division of Technology, Industry and Economics (DTIE) and International Commission on Large Dams (ICOLD). Bulletin 121.

Jacobs, J. (1969) The Economy of Cities. New York: Random House.

Jenning, S.R. and J. Krueger (1997) Clean tailings reclamation: tailings reprocessing for sulfide removal and vegetation establishment. Proc. 12th Ann, Conference on Hazardous Waste Research. Kansas City: 62-75.

Jeong, Y.-S., K. Matsubae-Yokoyama, H. Kubo, J-J. Pak and T. Nagasaka (2009). Substance flow analysis of phosphorus and manganese correlated with South Korean steel industry. Resources, Conservation and Recycling 53: 479-489.

Johnson, J., E. Harper, R. Lifset and T.E. Graedel (2007): Dining at the Periodic Table: Metals Concenrations as They Relate to Recycling. Environmental Science and Technology 41 (5): 17591765.

Jones, P.T., D. Geysen, A. Rossy and K. Binge (2010) Enhanced Landfill Mining (ELFM) and Enhanced Waste Management (EWM); essential components for the transition to Sustainable Materials Management (SMM). In P.T. Jones and Tielemans, Y. (eds.) Enhanced Landfill Mining and the transition to Sustainable Materials Management, pp. 19-37. Houthalen- Helchteren; Haletra.

Karlberg, A.K. (2010) LKAB:s skrothögar är värda miljarder/LKAB's scrap heaps are worth billions. Ny teknik 2010-11-09 [online]

http://www.nyteknik.se/nyheter/bygg/anlaggningsbyggen/article2504635.ece\#comments [access: 2011-10-31].

Kapur, A. and T.E. Graedel (2006) Copper mines above and below the ground. Environmental Science and Technology 40: 3135-3141.

KlingImair, M. and J. Fellner (2010) Urban Mining in Times of Raw Material Shortage. J. of Industrial Ecology 14 (4): 666-679.

Kollikkathara, N., H. Feng and E. Stern (2009) A purview of waste management evolution: Special emphasis on USA. Waste Management 29: 974-985.

Kosich, D. (2010) Massive Hungarian tailings disaster focuses international spotlight on mining wastes. Mineweb 2010-10-06 [online] http://www.mineweb.com/mineweb/view/mineweb/en/page68?oid=112449\&sn=Detail [access: 2011-11-07]

Krook, J., N. Svensson, M. Eklund, N. Johansson and P. Frändegård (2010) Landfill mining: a review of three decades of research. ERSCP-EMSU conference, Delft, The Netherlands. October 25-29, 2010.

Krook, J., A. Carlsson, M. Eklund, P. Frändegård and N. Svensson (2011) Urban mining: hibernating copper stocks in local power grids. J. of Cleaner Production 19: 1052-1056.

Kuo, N.-W., H.-W. Ma, Y.-M. Yang, T.-Y. Hsiao and C.-M. Huang (2007) An investigation on the potential of metal recovery from the municipal waste incinerator in Taiwan. Waste Management 27 (11): 1673-1679.

Kurian, J., S. Esakku, K. Palanivelu and A. Selvam (2003) Studies on landfill mining at solid waste dumpsites in India. Proceedings Sardinia '03, Ninth International Landfill Symposium, Cagliari, Italy: 248-255.

Kurian, J., S. Esakku and R. Nagendran (2007) Mining compost from dumpsites and bioreactor landfills. Int. J. Environmental Technology and Management 7: 317-325.

Lewis, R.S. and G.B. Clark (1964) Elements of Mining, 3d ed. New York; John Wiley \& Sons.

Lichtensteiger, T. (2002) The Petrologic Evaluation. Berlin; Springer-Verlag.

Lind, B.B., A.-M. Fällman and L.B. Larsson (2001) Environmental impact of ferrochrome slag in road construction. Waste Management 21 (3): 255-264.

Liou, J.C. and N.L. Johnson (2006) Risks in Space from Orbiting Debris. Science 311: 340-341.

Melnik, M. (2004) Radioactive Scrap Metal Collectors Detained near Chornobyl. ITAR-TASS [online] http://www.nti.org/db/nistraff/2004/20040030.htm [access: 2011-10-31]. 
Moore, C.J., S.L Moore, M.K. Leecaster and S.B. Weisberg (2001) A comparison of plastic and plankton in the North Pacific central gyre. Marine Pollution Bulletin 42: 1297-1300.

Moore, C.J. (2008) Synthetic polymers in the marine environment: A rapidly increasing, long-term threat. Environmental Research 108 (2): 131-139.

Müller, D., T. Wang, B. Duval and T.E. Graedel (2006) Exploring the engine of anthropogenic iron cycles. PNAS 103: 16111-16116.

Nishida, S.-I. and S. Kawamoto (2011) Strategy for capturing of a tumbling space debris. Acta Astronautica 68 (1-2): 113-120.

Nollkaemper, A. (1994) Land-based dicharges of marine debris: from local to global regulation. Marine Pollution Bulletin 28 (11): 649-652.

OECD (1994) Decision of the Council on the reduction of transfrontier movements of wastes. 27 May 1988 C(88)90/Final amendment on 28th-29th July 1994-C(94)152/FINAL.

Opiela, J.N. (2009) A study of the material density distribution of space debris. Advances in Space Reserarch 43 (7): 1058-1064.

Ostrolenk, B. (1941) Economic Geography. Chicago: Richard D.Irwin.

Oswald, I. and A. Reller (2011) E-Waste: A Story of Trashing, Trading, and Valuable Resources. GAIA Ecological Perspectives for Science and Society 20 (1): 41-47.

Phipps, C.R., G. Albrecht, H. Friedman, D. Gavel, E.V. George, J. Murray, C. Ho, W. Priedhorsky, M.M. Michaelis and J.P. Reilly (1996) ORION: Clearing near-Earth space debris using a 20-kW, 530-nm, Earth-based, repetitively pulsed laser. Laser and Particle Beams 14: 1-44.

Pichel, W., J. Churnside, T. Veenstra, D. Foley, K. Friedman, R. Brainard, J. Nicoll, Q. Zheng and P. Clemente-Colon (2007) Marine debris collects within the North Pacific Subtropical Convergence Zone. Marine Pollution Bulletin 54: 1207-1211.

Pirrone, N. and K.R. Mahaffey (2005) Where we stand on mercury pollution and its health effects on regional and global scales. In N. Pirrone and K. Mahaffey (eds.), Dynamics of Mercury Pollution on Regional and Global Scales: Atmospheric Processes, Human Exposure Around the World, pp. 1-24. Norwell: Springer Publisher.

Rankokwane, B. and T.D. Gwebu (2006) Characteristics, threats and opportunities of landfill scavenging: The case of Gaborone-Botswana. GeoJournal 65 (3): 151-163.

Rathje, W. and C. Murphy (1992) Rubbish! The Archaeology of Garbage. New York; HarperCollins.

Rauch, J. (2009) Global mapping of Al, Cu, Fe, and Zn in-use stocks and in-ground resources. PNAS 106 (45): 18920-18925.

Regan, J. (2010) Covanta Energy and Project Kaisei Announce Joint Commitment to the Clinton Global Initiative. Covanta Energy [online] http://www.kaisei.g2directdigital.com/pdf/Covanta\%20Energy\%20and\%20Project\%20Kaisei\%20A nnounce\%20Joint-21sep.pdf [access: 2011-10-31].

Reijnders, L. (2003) Recovery of dissipated copper and the future of copper supply. Resources, Conservation and Recycling 38: 56-66.

Richard, D., R. Ambrosie, P. Zavoral and R. Zimmerman (1996) Reclaiming an old landfill site by landfill mining. A feasibility study. Proceedings of the twelfth international conference on solid waste technology and management, University of Pennsylvania, USA.

Richards, N. (1998) The history and archaeology of the Garden Island ships' graveyard, north arm of the Port River, Port Adelaide, South Australia. Australian Archaeology 47: 70.

Rickard, T.A. (1932) Man and metals, vols. 1 and 2. New York: McGraw-Hill.

Richardson I.G., A.R. Brough, G.W. Groves and C.M. Dobson (1994) The characterization of hardened alkali-activated blast-furnace slag pastes and the nature of the calcium silicate hydrate (C-S-H) phase. Cement and Concrete Research 24 (5): 813-829.

Ridden, P. (2010)Electrolux announces first Vac from the Sea vacuum cleaners. Gizmaz [online] http://www.gizmag.com/vac-from-the-sea-plastic-used-in-vacuum-cleaner-manufacture/16751/ [access: 2011-10-31]. 
Savage, G.M., C.G. Golueke and E.L. von Stein (1993) Landfill mining: Past and present. Biocycle 34: $58-61$.

Saxena, M. and L.K. Dhimole (2006) Utilization and value addition of Copper tailings as an extender for development of paints. J. of Hazardous Materials 129 (1-3): 50-57.

Sidebottom, A., J. Belur, K. Bowers, L. Tompson and S. Johnson (2011) Theft in Price-Volatile Markets: On the Relationship between Copper Price and Copper Theft. J. of Research in Crime and Delinquency 48 (1): 396-418.

Smith, H.S. (2006) Comments pertaining to the discussion document: The Cooke uranium project; Environmental impact assessment (EIA) for rand uranium proposed development of a new longterm tailings storage facility (TSF) and associated booster station, pipelines \& routes in Gauteng province. APChem [online] http://www.fse.org.za/downloads/CookeUraniumProject.pdf [access: 2011-10-31].

Spatari, S., M. Bertram, R. B. Gordon, K. Henderson and T.E. Graedel (2005) Twentieth century copper stocks and flows in North America: A dynamic analysis. Ecological Economics 54: 37 - 51.

Stepanov, V.S. and A.G. Romanenko (1977) Operation without slag dumps. Metallurgist 21 (3): 194196.

SwedEnergy (2009) Hantering av uttjänt kabel/Management of worn-out cables. HMS 04:09.

Sörme, L., B. Bergbäck and U. Lohm (2001a) Goods in the anthroposphere as a metal emissions source-a case study of Stockholm, Sweden. Water, Air, and Soil Pollution focus 1 (3-4): 213-227.

Sörme, L., B. Bergbäck, and U. Lohm (2001b) Century perspective of heavy metal use in urban areas: $A$ case study in Stockholm. Water, Air and Soil Pollution focus 1 (3-4): 197- 211.

Tateda, M., M. Ike and M. Fujita (1997) Loss of metallic elements associated with ash disposal and social impacts. Resources, Conservation and Recycling 19 (2): 93-108.

UNEP (2010) Metal stocks in society. International Panel for Sustainable Resource Management, Working Group on the Global Metal Flows.

UN-HABITAT (2010) Solid Waste Management in the World's Cities: Water and Sanitation in the World's Cities 2010. London; Earthscan Ltd.

USGS (2010) Mineral commodity summaries 2010. U.S. Geological Survey.

van Beers, D. and T.E. Graedel (2007) Spatial characterisation of multilevel in-use copper and zinc stocks in Australia. J. of Cleaner Production 15 (8-9): 849- 861.

van Passel, S., S. de Gheldere, M. Dubois, J. Eyckmans and K. van Acker (2010) Exploring the socioeconomics of Enhanced Landfill Mining. In P.T. Jones and Y. Tielemans (eds.) Enhanced Landfill Mining and the transition to Sustainable Materials Management, pp. 247-264. HouthalenHelchteren; Haletra.

Wang, T., D. Müller and T.E. Graedel (2007) Forging the anthropogenic iron cycle. Environment Science and Technology 41 (14): 5120 - 5129.

Wendell, J. (2005) Cables- Societal Stock and Potential for Increased Recycling. Master Thesis. Linköping University, Sweden.

Whiteacre, K. and R. Howes (2009) Scrap Yards and Metal theft Insurance Claims in 51 U.S. Cities. Community Research Center. University of Indianapolis [online] http://www.wasterecyclingnews.com/pictures/NICBClaimsStudyResearchBrief2.pdf [access: 2011-10-31].

Williamson, R.A. (1991) The Growing Hazard of Orbiting Debris. Issues in Science and Technology 8 (1): 77-82.

Wilson, M.P., L. Balmer, M.J. Given, S.J. MacGregor, J.W. Mackersie and I.V. Timoshkin (2006) Application of electric spark generated high power ultrasound to recover ferrous and non-ferrous metals from slag waste. Minerals Engineering 19 (5): 491-499.

Wittmer, D. and T. Lichtensteiger (2007) Development of anthropogenic raw material stocks: a retrospective approach for prospective scenarios. Minerals and Energy 22: 62-71. 


\section{9 words}

Yi, Z.L., H.H. Sun, X.Q. Wei and C. Li (2009) Iron ore tailings used for the preparation of cementitious material by compound thermal activation. Int. J. Mineral Metallurgy and Materials 16 (3): 355358.

Zanetti, M. and A. Godio (2006) Recovery of foundry sands and iron fractions from an industrial waste landfill. Resources, Conservation and Recycling 48: 396-411. 